\title{
Cuprophilia: dye-sensitized solar cells with copper(I) dyes and copper(I)/(II) redox shuttles
}

Mariia Karpacheva, ${ }^{a, b}$ Frederik J. Malzner, ${ }^{a, b}$ Cedric Wobill, ${ }^{a, b}$ Annika Büttner,, ${ }^{a, b}$ Edwin C. Constable ${ }^{a}$ and Catherine E. Housecroft ${ }^{\star a}$

aDepartment of Chemistry, University Basel, BPR 1096, Mattenstrasse 24a, CH-4058 Basel, Switzerland. E-mail: catherine.housecroft@unibas.ch

${ }^{\mathrm{b}}$ These authors (MK, FJM, CW, AB) contributed equally to this work.

\section{Abstract}

With a goal of designing dye-sensitized solar cells (DSCs) containing only Earthabundant components to achieve sustainable energy conversion, DSCs with heteroleptic copper(I)-based dyes and homoleptic copper(I)/(II) redox shuttles have been investigated. By using a phosphonic acid anchor, and 4,4'-dimethoxy-6,6'dimethyl-2,2'-bipyridine as the ancillary ligand in the dye and in the electrolyte, a DSC photoconversion efficiency of $2.06 \%$ (38.1\% relative to $\mathrm{N} 719$ set at $100 \%)$ was achieved. The results demonstrate the potential for all-copper-based DSCs, opening the way for further dye and electrolyte optimization.

\section{Keywords}

copper; dye-sensitized solar cell; sensitizer; electrolyte; sustainable energy conversion 


\section{Introduction}

Exceptionally high levels of greenhouse gases on Earth were recorded in 2017 [1]. The impact on global temperatures is well-established [2] and a drastic reduction of greenhouse gas emissions must be targeted. The combustion of fossil fuels is a major contributor to $\mathrm{CO}_{2}$ emissions and a paradigm shift to renewable energy sources is essential. Towards this end, our interests lie in the development of dye-sensitized solar cells (DSCs) which first came to the fore with the work of O'Regan and Grätzel [3]. Since these pioneering studies, the area has matured [4], with photoconversion efficiencies $(\eta)$ reaching $\sim 11-$ $14 \%$ with ruthenium-based, metal-free organic or zinc(II) porphyrin-based sensitizers [5]. While state-of-the-art ruthenium dyes and high DSC efficiencies are synonymous, the scarcity of ruthenium in the Earth's crust $(\approx 0.001 \mathrm{ppm}[6])$ and its associated high cost are a disadvantage for large scale applications. In contrast, DSCs based on copper(I) sensitizers could provide a sustainable alternative as the Earth's crust abundance of $\mathrm{Cu}$ is $\approx 50 \mathrm{ppm}$ [6].

We and others $[7,8]$ have demonstrated the viability of DSCs sensitized by bis(diimine)copper(I) complexes. Effective screening of dyes is carried out using a 'surface-as-ligand' approach in which heteroleptic $\left[\mathrm{Cu}\left(\mathrm{L}_{\text {anchor }}\right)\left(\mathrm{L}_{\text {ancillary }}\right)\right]^{+}$ dyes are assembled in situ on $\mathrm{FTO} / \mathrm{TiO}_{2}$ electrodes [7]. We have focused upon dye optimization through variously functionalizing the anchoring and ancillary ligands [9-14]. With an $\mathrm{I}^{-} / \mathrm{I}_{3}^{-}$redox shuttle [15], copper-based dyes reach values of $\eta>3 \%$ compared to $\eta=7.12-7.63 \%$ for the benchmark ruthenium dye N719 $[9,11,16,17]$ and we have also shown that combining copper(I) dyes with a $\mathrm{Co}^{2+} / \mathrm{Co}^{3+}$-based electrolyte is advantageous [18]. 
The choice of electrolyte is essential in ensuring efficient transport of electrons in a DSC to regenerate the dye. The $\mathrm{I}^{-} / \mathrm{I}_{3}^{-}$redox shuttle is the conventional choice, but uses a non-abundant element (Earth's crust abundance of iodine $\approx 0.14 \mathrm{ppm}$, seawater abundance $\approx 0.05 \mathrm{ppm}[6])$. Among alternative redox couples $[19,20], \mathrm{Cu}^{+} / \mathrm{Cu}^{2+}$ has emerged as a potential candidate. Initial studies with $\mathrm{N} 719$ as dye and $\left[\mathrm{Cu}(\mathrm{dmphen})_{2}\right]^{+/ 2+}$ as electrolyte (dmphen $=2,9$-dimethyl-1,10-phenanthroline) achieved $\eta=1.4 \%$ [21]. Brugnati et al. described a wider screening of ligands in the copper complexes [22], and Bai et al. improved the performance to $7.0 \%$ using an organic sensitizer [23]. Combining the organic dye LEG4 (Scheme S1†) with $\left[\mathrm{Cu}(\mathrm{dmphen})_{2}\right]^{+/ 2+}$ gave $\eta$ $=8.3 \%,{ }^{24}$ thereby reviving interest in copper redox shuttles [25-30]. A significant advantage of these systems is that the copper(I/II) redox couple increases $V_{\mathrm{OC}}$. A combination of a $\mathrm{Cu}^{+} / \mathrm{Cu}^{2+}$ couple with a copper $(\mathrm{I})$ sensitizer is attractive in terms of DSCs with Earth-abundant components. We have already demonstrated their compatibility for DSC applications by using scanning electrochemical microscopy (SECM) to probe the surface charges in DSCs containing a heteroleptic $\left[\mathrm{Cu}\left(\mathrm{L}_{\text {anchor }}\right)\left(\mathrm{L}_{\text {ancillary }}\right)\right]^{+}$dye and a homoleptic $\left[\mathrm{Cu}\left(\mathrm{L}_{\text {ancillary }}\right)_{2}\right]^{+/ 2+}$ redox couple [31]. An advantage of such systems is that labile $\left[\mathrm{Cu}\left(\mathrm{L}_{\text {ancillary }}\right)_{2}\right]^{+}$present in the electrolyte provides a source of $\mathrm{L}_{\text {ancillary }}$ to regenerate the dye $[10,12]$.

We now present an investigation of DSCs containing $\left[\mathrm{Cu}\left(\mathrm{L}_{\text {anchor }}\right)\left(\mathrm{L}_{\text {ancillary }}\right)\right]^{+}$ dyes and $\left[\mathrm{Cu}\left(\mathrm{L}_{\text {ancillary }}\right)_{2}\right]^{+/ 2+}$ electrolytes in which $L_{\text {anchor }}$ is the phosphonic acid 1 and $L_{\text {ancillary }}$ is one of the diimines 2-6 (Scheme 1). 


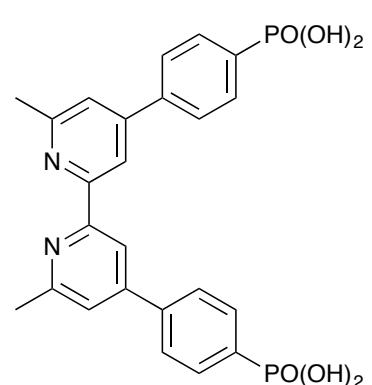

1

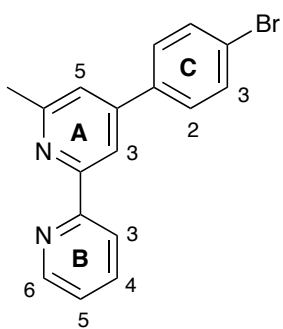

3

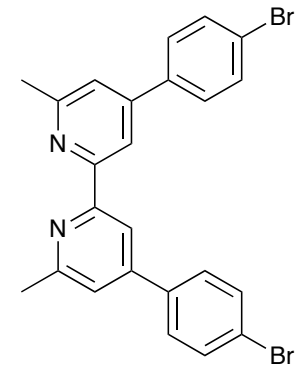

2

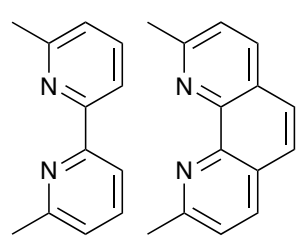

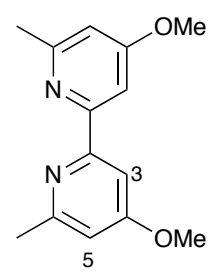

6

Scheme 1: Structure of anchoring ligand 1 and ligands 2-6 used as ancillary ligands in the dyes and in homoleptic copper(I)/(II) redox couples. Labelling in $\mathbf{3}$ and $\mathbf{6}$ is for NMR spectroscopic assignments.

\section{Results and Discussion}

\subsection{Copper(I) complexes for dyes and electrolytes}

We have previously shown that dyes incorporating 1 as the anchoring ligand give superior DSC performances over those with related carboxylic acid anchors $[32,33]$. An initial combination was $[\mathrm{Cu}(\mathbf{1})(2)]^{+}$and $\left[\mathrm{Cu}(2)_{2}\right]^{+/ 2+}$ in order to parallel one of the combinations used in our previously reported SECM study [31]. Ligand 3 (Scheme 1) contains one 4-bromophenyl unit and a methyl group in the bpy 6-position to stabilize the copper(I) species, but is sterically less demanding than $\mathbf{2}$. Ligands $\mathbf{4}$ and $\mathbf{5}$ have previously been used in copper-based electrolytes [21,23-26,30]. Ligand 6 (Scheme 1) contains electron-donating methoxy groups. The compounds $\left[\mathrm{Cu}(2)_{2}\right]\left[\mathrm{PF}_{6}\right]$ [33], $\left[\mathrm{Cu}(4)_{2}\right]\left[\mathrm{PF}_{6}\right][34]$ and $\left[\mathrm{Cu}(5)_{2}\right]\left[\mathrm{PF}_{6}\right][30]$ have been reported. Ligand 6 was prepared according to the methods summarized in Scheme 2. The ${ }^{1} \mathrm{H}$ and ${ }^{13} \mathrm{C}$ NMR spectra 
were consistent with the expected substitution pattern, the methoxy group being characterized by signals at $\delta 3.92 \mathrm{ppm}$ and $\delta 55.3 \mathrm{ppm}$ in the ${ }^{1} \mathrm{H}$ and ${ }^{13} \mathrm{C}$ NMR spectra, respectively. The methyl groups adjacent to the $\mathrm{N}$ atoms in 6 gave rise to ${ }^{1} \mathrm{H}$ and ${ }^{13} \mathrm{C}$ NMR resonances at $\delta 2.57 \mathrm{ppm}$ and $\delta 24.8 \mathrm{ppm}$, respectively. In the electrospray (ESI) mass spectrum, the base peak at $\mathrm{m} / \mathrm{z} 245.10$ corresponded to the $[6+\mathrm{H}]^{+}$ion.
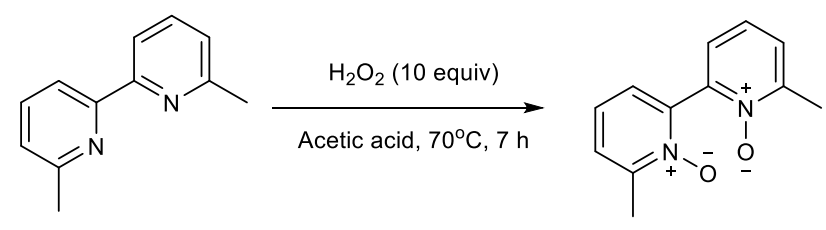

$6 a$

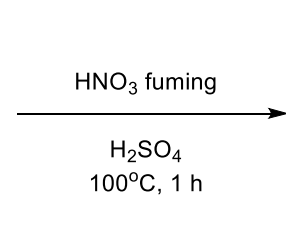

$100^{\circ} \mathrm{C}, 1 \mathrm{~h}$

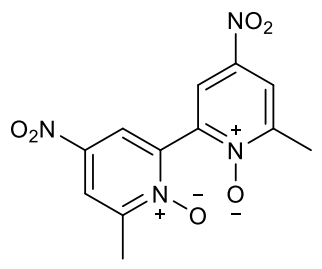

6b<smiles>COc1cc(C)nc(-c2cc(OC)cc(C)n2)c1</smiles>

Scheme 2. Synthetic route to compound 6.

The complexes $\left[\mathrm{Cu}(3)_{2}\right]\left[\mathrm{PF}_{6}\right]$ and $\left[\mathrm{Cu}(6)_{2}\right]\left[\mathrm{PF}_{6}\right]$ were prepared by treatment of $\left[\mathrm{Cu}(\mathrm{MeCN})_{4}\right]\left[\mathrm{PF}_{6}\right]$ with two equivalents of 3 or $\mathbf{6}$ and were isolated as dark red or orange solids in 97 and $83 \%$ yields, respectively. The ESI mass spectrum of each complex exhibited a peak envelope arising from the $\left[\mathrm{CuL}_{2}\right]^{+}$ion $(\mathrm{m} / \mathrm{z}=712.98$ for $\left[\mathrm{Cu}(3)_{2}\right]^{+}$and 551.16 for $\left.\left[\mathrm{Cu}(6)_{2}\right]^{+}\right) .{ }^{1} \mathrm{H}$ and ${ }^{13} \mathrm{C}$ NMR data (see Experimental Section) were assigned using $2 \mathrm{D}$ methods. The solution absorption spectra of $\left[\mathrm{CuL}_{2}\right]\left[\mathrm{PF} F_{6}\right](\mathrm{L}=$ 2-6) show a characteristic metal-to-ligand charge transfer (MLCT) band at $\lambda_{\max }=$ 488, 467, 453, 455, $444 \mathrm{~nm}$, respectively, for complexes with L = 2 [33], 3 (Fig. 1), 4 [34], 5 [30] or 6 (Fig. 1). The MLCT band for $\left[\mathrm{Cu}(2)_{2}\right]\left[\mathrm{PF}_{6}\right]$ is the most red shifted as a 
result of the extended m-system. The absorption spectra also show intense bands in the UV region assigned to ligand-based $\pi^{*} \leftarrow \pi$ and $\pi^{*} \leftarrow n$ transitions.

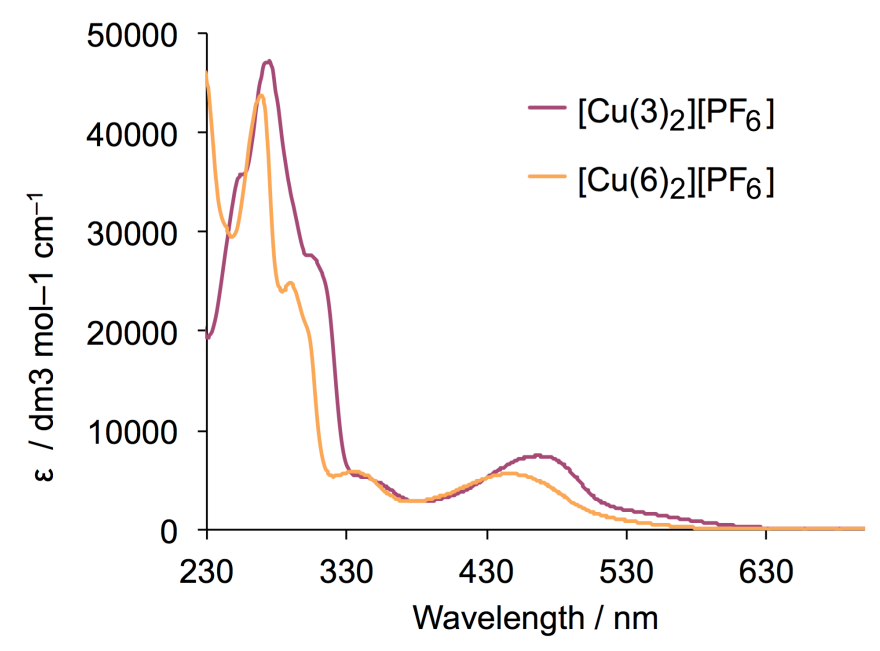

Fig. 1: Solution absorption spectra of $\left[\mathrm{Cu}(3)_{2}\right]\left[\mathrm{PF}_{6}\right]$ and $\left[\mathrm{Cu}(6)_{2}\right]\left[\mathrm{PF}_{6}\right]\left(\mathrm{CH}_{2} \mathrm{Cl}_{2}\right.$, $\left.5 \times 10^{-5} \mathrm{~mol} \mathrm{dm}^{-3}\right)$.

Table 1: Cyclic voltammetric data for $\left[\mathrm{CuL}_{2}\right]\left[\mathrm{PF}_{6}\right](\mathrm{L}=2-6)$ with respect to $\mathrm{Fc} / \mathrm{Fc}^{+} ; \mathrm{CH}_{2} \mathrm{Cl}_{2}$ solutions with [ $\left.{ }^{\mathrm{n}} \mathrm{Bu}_{4} \mathrm{~N}\right]\left[\mathrm{PF}_{6}\right]$ as supporting electrolyte and scan rate of $0.1 \mathrm{~V} \mathrm{~s}^{-1}$. Processes are reversible.

\begin{tabular}{|l|l|l|}
\hline Complex & $\begin{array}{l}E_{1 / 2}^{o x} / \mathrm{V} \\
\left(E_{\mathrm{pc}}-E_{\mathrm{pa}} / \mathrm{mV}\right)\end{array}$ & \\
\hline$\left[\mathrm{Cu}(\mathbf{2})_{2}\right]\left[\mathrm{PF}_{6}\right]$ & $+0.42(94)$ & 34 \\
\hline$\left[\mathrm{Cu}(\mathbf{3})_{2}\right]\left[\mathrm{PF}_{6}\right]$ & $+0.17(105)$ & this work \\
\hline$\left[\mathrm{Cu}(\mathbf{4})_{2}\right]\left[\mathrm{PF}_{6}\right]$ & $+0.35^{\mathrm{b}}$ & 26 \\
\hline$\left[\mathrm{Cu}(\mathbf{5})_{2}\right]\left[\mathrm{PF}_{6}\right]$ & $+0.41(66)^{\mathrm{a}}$ & this work \\
\hline$\left[\mathrm{Cu}(\mathbf{6})_{2}\right]\left[\mathrm{PF}_{6}\right]$ & $+0.19(75)$ & this work \\
\hline
\end{tabular}

${ }^{\mathrm{a}}$ This value compares with $+0.93 \mathrm{~V} v \mathrm{~s}$. SHE from ref. 26 , and with $+0.50 \mathrm{~V} v \mathrm{~s}$. $\mathrm{Fc} / \mathrm{Fc}^{+}$from ref. [36].

${ }^{\mathrm{b}}$ The original value was $+0.97 \mathrm{~V} v \mathrm{~s}$. SHE and was adjusted by $-0.62 \mathrm{~V}$ to be $v s$. $\mathrm{Fc}_{\mathrm{Fc}}{ }^{+}[37]$. 
Each homoleptic compound undergoes a reversible oxidation process and the oxidation potentials (vs. $\left.\mathrm{Fc} / \mathrm{Fc}^{+}\right)$are summarized in Table 1. Fig. $\mathrm{S} 1$ shows cyclic voltammograms of $\left[\mathrm{Cu}(3)_{2}\right]\left[\mathrm{PF}_{6}\right],\left[\mathrm{Cu}(\mathbf{5})_{2}\right]\left[\mathrm{PF}_{6}\right]$ and $\left[\mathrm{Cu}(\mathbf{6})_{2}\right]\left[\mathrm{PF}_{6}\right]$. Oxidation of copper(I) in $\left[\mathrm{Cu}(2)_{2}\right]\left[\mathrm{PF}_{6}\right],\left[\mathrm{Cu}(4)_{2}\right]\left[\mathrm{PF}_{6}\right]$ and $\left[\mathrm{Cu}(5)_{2}\right]\left[\mathrm{PF}_{6}\right]$ occurs at similar potentials. In each of these complexes, the ligand has a 6,6'-Me $\mathrm{M}_{2} \mathrm{bpy}$ unit with the 6,6'substituents stabilizing the tetrahedral geometry of $\mathrm{Cu}^{+}$. In contrast, in $\left[\mathrm{Cu}(3)_{2}\right]\left[\mathrm{PF}_{6}\right]$ each ligand has one 6-Me group and oxidation occurs at lower potential. This trend is consistent with that observed on going from $\left[\mathrm{Cu}(\mathbf{4})_{2}\right]^{+}$(Table $1,4=6,6^{\prime}-\mathrm{Me}_{2} \mathrm{bpy}$ ) to $\left[\mathrm{Cu}(6-\mathrm{Mebpy})_{2}\right]^{+}$for which the $\mathrm{Cu}^{+} / \mathrm{Cu}^{2+}$ oxidation is at $+0.03 \mathrm{~V}$; the original value was reported as $+0.41 \mathrm{~V} v$ s. SCE [38] and has been adjusted by $-0.38 \vee[37]$ to be $v s$. $\mathrm{Fc} / \mathrm{Fc}^{+}$. The introduction of electron-donating methoxy groups in $\left[\mathrm{Cu}(6)_{2}\right]\left[\mathrm{PF}_{6}\right]$ also results in a lowering of the oxidation potential compared to $\left[\mathrm{Cu}(4)_{2}\right]\left[\mathrm{PF}_{6}\right]$.

\subsection{Assembly of DSCs}

Working electrodes were first prepared using our 'surfaces-as-ligands' strategy [7] which involves initially functionalizing the $\mathrm{TiO}_{2}$ electrode with the anchoring ligand (in this case ligand 1) followed by treatment with a homoleptic copper(I) complex which undegoes ligand exchange to yield heteroleptic copper(l) sensitizers. The dyes $[\mathrm{Cu}(\mathbf{1})(\mathbf{2})]^{+},[\mathrm{Cu}(\mathbf{1})(\mathbf{3})]^{+},[\mathrm{Cu}(\mathbf{1})(\mathbf{4})]^{+},[\mathrm{Cu}(\mathbf{1})(\mathbf{5})]^{+}$and $[\mathrm{Cu}(\mathbf{1})(\mathbf{6})]^{+}$were assembled on screen-printed $\mathrm{TiO}_{2}$ electrodes with or without a scattering layer for DSC fabrication or recording solid-state absorption spectra, respectively. The absorption spectra (Fig. S2) of the dye-functionalized electrodes showed MLCT bands at $\sim 465 \mathrm{~nm}$.

The electrolytes comprised $\left[\mathrm{CuL}_{2}\right]\left[\mathrm{PF}_{6}\right](\mathrm{L}=2-6)$ and $\left[\mathrm{CuL}_{2}\right]\left[\mathrm{PF}_{6}\right]_{2}$ in a nominal 5:1 ratio in $\mathrm{MeCN}$ with $\mathrm{LiPF}_{6}$ and 4-tert-butylpyridine (TBP) additives. The copper(II) salts were prepared by oxidation of the corresponding copper $(\mathrm{I})$ salt using $\left.\left[\mathrm{NO}^{-}\right] \mathrm{BF}_{4}\right]$. After anion exchange using $\mathrm{NH}_{4} \mathrm{PF}_{6}$, the copper(II) salts with ligands 3-6 were 
isolated as blue-green solids. For 2, the product turned from green to brown-red indicating reduction or partial reduction to copper(I). Variation in colour of $\left[\mathrm{Cu}(\text { tmby })_{2}\right][\mathrm{TFSI}]_{2} \quad\left(\right.$ tmby $=$ 4,4,6,6-tetramethyl-2,2'-bipyridine, $\mathrm{TFSI}^{-}=$ trifluorosulfonylimide) arising from copper(I) species has been noted in the preparation of $\left[\mathrm{Cu}(\mathrm{tmbp})_{2}\right]^{+/ 2+}$ electrolytes, [39] underlining the difficulties of stabilizing the copper(II) component of the electrolyte with bpy ligands that contain a 6,6 'dimethyl substitution pattern designed to stablize the copper(I) species. We note that this is an inherent issue with electrolytes based on $\left[\mathrm{CuL}_{2}\right]^{+/ 2+}$ redox couples which have a significant change in preferred coordination geometry (and number) between the two oxidation states. This is not an issue for other metal-based electrolytes, for example $\left[\mathrm{Co}(\mathrm{bpy})_{3}\right]^{2+/ 3+}$ redox couples, in which the ground state geometries are extremely similar. This problem is exacerbated by the fact that the ligand design for the electrolyte is predicated upon the need to stabilize the copper(I) state through the presence of $6,6^{\prime}$-dimethyl substituents which in turn destabilize the $\left[\mathrm{CuL}_{2}\right]^{2+}$ species. Mass spectrometric data for the $\left[\mathrm{CuL}_{2}\right]\left[\mathrm{PF}_{6}\right]_{2}(\mathrm{~L}=2-6)$ salts are given in the experimental section. Table 2 gives the nominal compositions of each electrolyte. The ratio of $\left[\mathrm{CuL}_{2}\right]\left[\mathrm{PF}_{6}\right](\mathrm{L}=\mathbf{2 - 6})$ and $\left[\mathrm{CuL}_{2}\right]\left[\mathrm{PF}_{6}\right]_{2}$ was $5: 1$. However the exact ratio assumes pure copper(I) and copper(II) salts; the degree of copper(I) species in the copper(II) salts has not been quantified but appears from colour not to be significant for $\left[\mathrm{CuL}_{2}\right]\left[\mathrm{PF}_{6}\right]$ with $\mathrm{L}=3-6$. Differing solubilities of the salts in MeCN resulted in the different concentrations shown in Table 2. The complexes containing ligand 2 were particularly poorly soluble.

For each dye/electrolyte combination, duplicate DSCs were made and cells were fully masked. 
Table 2. Electrolyte compositions. The solvent was $\mathrm{MeCN}$.

\begin{tabular}{|c|c|c|c|c|}
\hline & $\begin{array}{c}{\left[\mathrm{Cu}\left(\mathrm{L}_{2}\right]\left[\mathrm{PF}_{6}\right]\right.} \\
/ \mathrm{mol} \mathrm{dm}^{-3}\end{array}$ & $\begin{array}{c}{\left[\mathrm{Cu}(\mathbf{L})_{2}\right]\left[\mathrm{PF}_{6}\right]_{2}} \\
/ \mathrm{mol} \mathrm{dm}^{-3}\end{array}$ & $\begin{array}{c}\text { 4-tert-Butylpyridine } \\
/ \mathrm{mol} \mathrm{dm}^{-3}\end{array}$ & $\begin{array}{c}\mathrm{LiPF}_{6} \\
/ \mathrm{mol} \mathrm{dm}^{-3}\end{array}$ \\
\hline$\left[\mathrm{Cu}(\mathbf{2})_{2}\right]^{+/ 2+}$ & 0.02 & 0.004 & 0.5 & 0.1 \\
\hline$\left[\mathrm{Cu}(\mathbf{3})_{2}\right]^{+/ 2+}$ & 0.10 & 0.02 & 0.5 & 0.1 \\
\hline$\left[\mathrm{Cu}(\mathbf{4})_{2}\right]^{+/ 2+}$ & 0.20 & 0.04 & 0.5 & 0.1 \\
\hline$\left[\mathrm{Cu}(\mathbf{5})_{2}\right]^{+/ 2+}$ & 0.20 & 0.04 & 0.5 & 0.1 \\
\hline$\left[\mathrm{Cu}(\mathbf{6})_{2}\right]^{+/ 2+}$ & 0.20 & 0.04 & 0.5 & 0.1 \\
\hline
\end{tabular}

\subsection{DSC performances}

Table 3 summarizes the DSC parameters of the best performing cell of each duplicate set; Table S1 presents all data. Fig. 2 and S3 show J-V curves. The combination of $[\mathrm{Cu}(\mathbf{1})(2)]^{+}$and $\left[\mathrm{Cu}(2)_{2}\right]^{+/ 2+}$ (the system studied by SECM [31]) did not perform well and showed the lowest overall efficiency $(\eta=0.33 \%)$. The low value of $J_{\mathrm{SC}}\left(1.10 \mathrm{~mA} \mathrm{~cm}^{-2}\right)$ was consistent with the low maximum external quantum efficiency $\left(E Q E_{\max }\right)\left(<1 \%\right.$ at $\left.\lambda_{\max }=490 \mathrm{~nm}\right)$. A contributing factor to the poor performance is likely to be the poor solubility of $\left[\mathrm{Cu}(2)_{2}\right]\left[\mathrm{PF}_{6}\right]$ and $\left[\mathrm{Cu}(2)_{2}\right]\left[\mathrm{PF}_{6}\right]_{2}$ in $\mathrm{MeCN}$, and the difficulty in isolating the latter complex (see above). A change to dye $[\mathrm{Cu}(\mathbf{1})(3)]^{+}$and redox couple $\left[\mathrm{Cu}(3)_{2}\right]^{+/ 2+}$ lead to a small increase in $J_{\mathrm{sc}}\left(1.10\right.$ to $\left.1.69 \mathrm{~mA} \mathrm{~cm}{ }^{-2}\right)$ and $V_{\mathrm{OC}}(558$ to $662 \mathrm{mV})$. However, it is significant that for the $[\mathrm{Cu}(\mathbf{1})(\mathbf{3})]^{+} /\left[\mathrm{Cu}(\mathbf{3})_{2}\right]^{+/ 2+}$ combination, $V_{\mathrm{OC}}$ (Table 3 and Fig. S3a) exceeds that for N719 (662 vs. $614 \mathrm{mV}$ ). This trend becomes more pronounced on going to other $\mathrm{Cu}^{+/ 2+}$ electrolytes (see below). For the better performing electrolyte $\left[\mathrm{Cu}(3)_{2}\right]^{+/ 2+}$, ancillary ligands $\mathbf{4}$ and $\mathbf{5}$ were also investigated, but $f f$ values and photoconversion efficiencies remained low (ff $\leq 55 \%, \eta=0.54-0.64 \%$ ). All DSCs with the $\left[\mathrm{Cu}(3)_{2}\right]^{+/ 2+}$ electrolyte showed comparable EQE spectra, exemplified in Fig. 3 for dye $[\mathrm{Cu}(1)(4)]^{+}\left(\mathrm{EQE}_{\max } 15 \%\right.$ at $\left.\lambda_{\max }=490 \mathrm{~nm}\right)$. 
Table 3. DSC parameters using $[\mathrm{Cu}(\mathbf{1})(\mathrm{L})]^{+}$with $\mathrm{L}=2-6$ and $\left[\mathrm{CuL}_{2}\right]^{+/ 2+}$. Measurements ${ }^{a}$ were made on the day of sealing the cell. See also Table S1.

\begin{tabular}{|c|c|c|c|c|c|c|}
\hline Dye & Electrolyte & $\begin{array}{c}J_{\mathrm{SC}} / \\
\mathrm{mA} \mathrm{cm}{ }^{-2}\end{array}$ & $V_{\mathrm{oc}} / \mathrm{mV}$ & $\mathrm{ff} / \%$ & $\eta / \%$ & Rel. $\eta / \%$ \\
\hline$[\mathrm{Cu}(1)(2)]^{+}$ & {$\left[\mathrm{Cu}(2)_{2}\right]^{+/ 2+}$} & 1.10 & 558 & 55 & 0.33 & 6.1 \\
\hline$[\mathrm{Cu}(1)(3)]^{+}$ & {$\left[\mathrm{Cu}(3)_{2}\right]^{+/ 2+}$} & 1.69 & 662 & 55 & 0.61 & 11.3 \\
\hline$[\mathrm{Cu}(\mathbf{1})(4)]^{+}$ & {$\left[\mathrm{Cu}(3)_{2}\right]^{+/ 2+}$} & 1.97 & 648 & 43 & 0.54 & 10.0 \\
\hline$[\mathrm{Cu}(1)(5)]^{+}$ & {$\left[\mathrm{Cu}(3)_{2}\right]^{+/ 2+}$} & 1.88 & 655 & 52 & 0.64 & 11.9 \\
\hline$[\mathrm{Cu}(1)(2)]^{+}$ & {$\left[\mathrm{Cu}(4)_{2}\right]^{+/ \mathrm{C}^{+}}$} & 2.14 & 784 & 66 & 1.12 & 20.7 \\
\hline$[\mathrm{Cu}(1)(3)]^{+}$ & {$\left[\mathrm{Cu}(4)_{2}\right]^{+/ 2+}$} & 2.15 & 710 & 55 & 0.84 & 15.6 \\
\hline$[\mathrm{Cu}(\mathbf{1})(\mathbf{4})]^{+}$ & {$\left[\mathrm{Cu}(4)_{2}\right]^{+/ 2+}$} & 2.29 & 689 & 60 & 0.95 & 17.6 \\
\hline$[\mathrm{Cu}(1)(5)]^{+}$ & {$\left[\mathrm{Cu}(4)_{2}\right]^{+/ 2+}$} & 2.21 & 679 & 64 & 0.97 & 18.0 \\
\hline$[\mathrm{Cu}(\mathbf{1})(\mathbf{6})]^{+}$ & {$\left[\mathrm{Cu}(4)_{2}\right]^{+/ 2+}$} & 2.27 & 702 & 61 & 0.97 & 18.0 \\
\hline$[\mathrm{Cu}(1)(3)]^{+}$ & {$\left[\mathrm{Cu}(5)_{2}\right]^{+/ 2+}$} & 3.09 & 812 & 72 & 1.82 & 33.7 \\
\hline$[\mathrm{Cu}(\mathbf{1})(\mathbf{4})]^{+}$ & {$\left[\mathrm{Cu}(\mathbf{5})_{2}\right]^{+/ 2+}$} & 2.80 & 796 & 73 & 1.63 & 30.2 \\
\hline$[\mathrm{Cu}(\mathbf{1})(5)]^{+}$ & {$\left[\mathrm{Cu}(5)_{2}\right]^{+/ 2+}$} & 2.98 & 804 & 74 & 1.76 & 32.6 \\
\hline$[\mathrm{Cu}(\mathbf{1})(\mathbf{6})]^{+}$ & {$\left[\mathrm{Cu}(5)_{2}\right]^{+/ 2+}$} & 2.66 & 788 & 73 & 1.53 & 28.3 \\
\hline$[\mathrm{Cu}(1)(4)]^{+}$ & {$\left[\mathrm{Cu}(\mathbf{6})_{2}\right]^{+/ 2^{+}}$} & 3.85 & 686 & 76 & 2.00 & 37.0 \\
\hline$[\mathrm{Cu}(\mathbf{1})(5)]^{+}$ & {$\left[\mathrm{Cu}(\mathbf{6})_{2}\right]^{+/ 2+}$} & 3.44 & 681 & 75 & 1.76 & 32.6 \\
\hline$[\mathrm{Cu}(\mathbf{1})(\mathbf{6})]^{+}$ & {$\left[\mathrm{Cu}(\mathbf{6})_{2}\right]^{+/ 2+}$} & 4.01 & 684 & 75 & 2.06 & 38.1 \\
\hline N719 & $\mathrm{I}^{-} / \mathrm{I}_{3}^{-}$ & 12.54 & 614 & 70 & 5.40 & 100.0 \\
\hline
\end{tabular}

${ }^{\mathrm{a}} \mathrm{J}_{\mathrm{SC}}=$ short-circuit current density; $V_{\mathrm{OC}}=$ open-circuit voltage; $f f=$ fill factor; $\eta=$ photoconversion efficiency; Rel. $\eta=\eta$ relative to $\mathrm{N} 719$ set to $100 \%$.

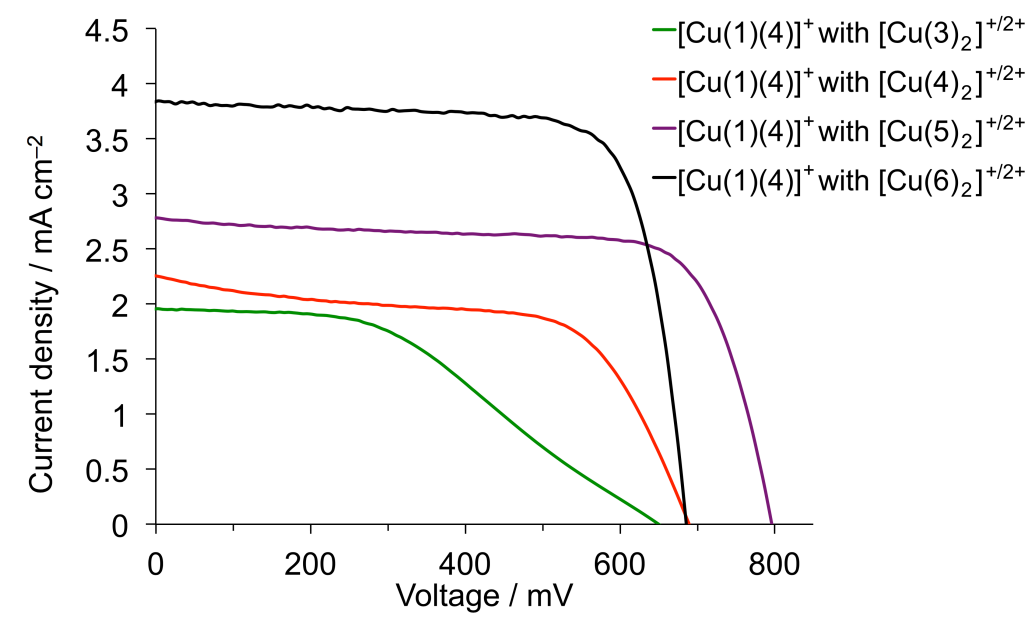

Fig. 2. J-V curves for the DSCs containing the dye $[\mathrm{Cu}(\mathbf{1})(\mathbf{4})]^{+}$and electrolytes $\left[\mathrm{Cu}(\mathbf{3})_{2}\right]^{+/ 2+},\left[\mathrm{Cu}(\mathbf{4})_{2}\right]^{+/ 2+},\left[\mathrm{Cu}(\mathbf{5})_{2}\right]^{+/ 2+},\left[\mathrm{Cu}(\mathbf{6})_{2}\right]^{+/ 2+}$ on the day of sealing the DSCs. 


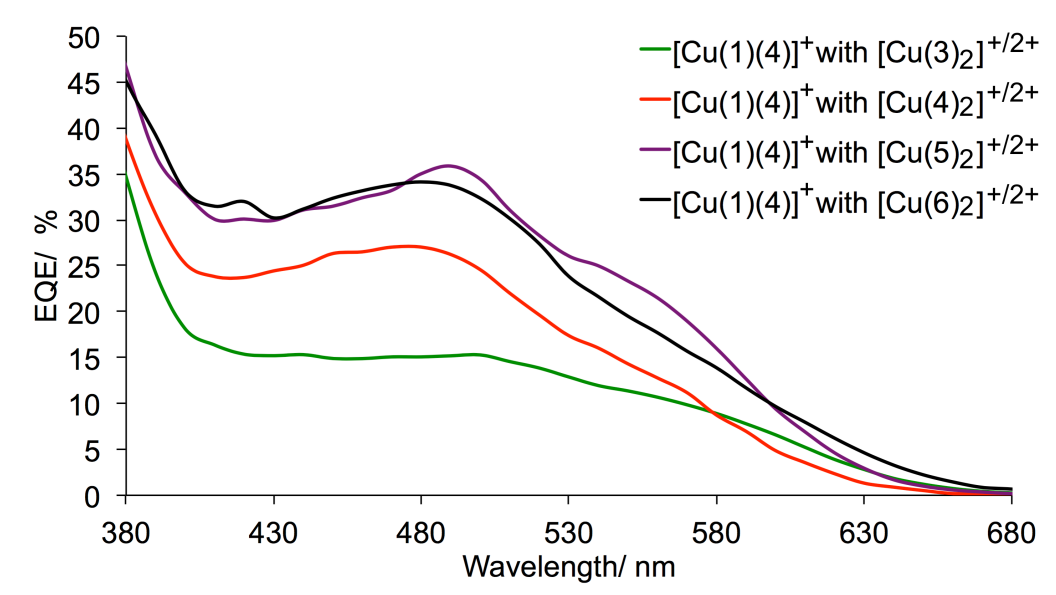

Fig. 3. EQE spectra for the DSCs containing the dye $[\mathrm{Cu}(\mathbf{1})(4)]^{+}$and electrolytes $\left[\mathrm{Cu}(3)_{2}\right]^{+/ 2+},\left[\mathrm{Cu}(4)_{2}\right]^{+/ 2+},\left[\mathrm{Cu}(5)_{2}\right]^{+/ 2+}$ or $\left[\mathrm{Cu}(6)_{2}\right]^{+/ 2+}$ recorded 1 day after sealing the DSCs.

Both $\left[\mathrm{Cu}(4)_{2}\right]^{+/ 2+}$ and $\left[\mathrm{Cu}(5)_{2}\right]^{+/ 2+}$ are efficient redox couples when combined with organic sensitizers $[23,24,26,30]$. In comparison to the copper-based DSCs detailed above, those containing dyes $[\mathrm{Cu}(\mathbf{1})(\mathrm{L})]^{+}(\mathrm{L}=\mathbf{2}, \mathbf{3}, \mathbf{4}$ or 5$)$ and $\left[\mathrm{Cu}(4)_{2}\right]^{+/ 2+}$ electrolyte exhibited improved efficiencies (up to $20.7 \%$ relative to N719 set at $100 \%$, Table 3 and S1). Higher $J_{\text {SC }}\left(2.14-2.29 \mathrm{~mA} \mathrm{~cm}{ }^{-2}\right)$ and $V_{\text {OC }}$ (679-784 mV) were observed (Fig. 2), although the fill factors remained relatively low (55-66\%, Table 3). DSC performance was not significantly affected by the ancillary ligand (Table 3). A change from $\left[\mathrm{Cu}(4)_{2}\right]^{+/ 2+}$ to $\left[\mathrm{Cu}(5)_{2}\right]^{+/ 2+}$ (i.e. from 6,6'-Me ${ }_{2}$ bpy to 2,9-Me ${ }_{2}$ phen copper-binding domains) lead to higher $J_{S c}, V_{O C}$ (Fig. 2) and ff values (Table 3). The best performing DSC had $J_{S C}=3.09 \mathrm{~mA} \mathrm{~cm}{ }^{-2}, V_{O C}=812 \mathrm{mV}$ and $f f=72 \%$. The latter value is comparable with the $\mathrm{ff}$ for the $\mathrm{N} 719$ reference DSC, and again, the $V_{\mathrm{OC}}$ was significantly higher for the copper- vs. N719-based DSC (812 vs. $614 \mathrm{mV})$. Further improvement was achieved by changing to a $\left[\mathrm{Cu}(6)_{2}\right]^{+/ 2+}$ redox couple, as is seen in both the $J-V$ curves and EQE spectra (Figs. 2 and 3), although the gain in $J_{S C}$ is at the expense of $V_{O C}$. DSCs with $[C u(1)(L)]^{+}(L=3,4$ or 5$)$ 
and $\left[\mathrm{Cu}(6)_{2}\right]^{+/ 2+}$ gave the highest $J_{\mathrm{SC}}$ values $(3.44$ to $4.01 \mathrm{~mA} \mathrm{~cm}$ ). With high $V_{\text {OC }}$ (Table 3 ) and ff values of 75 or $76 \%$, these DSCs gave the best overall efficiencies. A DSC with $[\mathrm{Cu}(\mathbf{1})(\mathbf{6})]^{+}$and $\left[\mathrm{Cu}(6)_{2}\right]^{+/ 2+}$ had an overall efficiency of $2.06 \%$ relative to $5.40 \%$ for $\mathrm{N} 719$. The relative efficiency of $38.1 \%$ (Table 3 ) is comparable to some of the best performing copper-based DSCs that contain an $\mathrm{I}^{-} / \mathrm{I}_{3}{ }^{-}$redox shuttle [9] and also compares favourably with DSCs with a copper-based dye and $\mathrm{Co}^{2+/ 3+}$ electrolyte [18]. The improvement in $J_{\mathrm{SC}}$ is the dominant contributing factor to enhanced photoconversion efficiency on changing the electrolyte from $\left[\mathrm{Cu}(3)_{2}\right]^{+/ 2+},\left[\mathrm{Cu}(4)_{2}\right]^{+/ 2+},\left[\mathrm{Cu}(5)_{2}\right]^{+/ 2+}$ to $\left[\mathrm{Cu}(6)_{2}\right]^{+/ 2+}$, as demonstrated for DSCs containing the dye $[\mathrm{Cu}(\mathbf{1})(\mathbf{4})]^{+}$in Fig. 2 and 3. Similar trends are observed for other dyes (Figs. S3 and S4). Fig. 4 displays the relative performances of the DSCs in Table 3, confirming that the effects of the electrolyte outweigh those of the ancillary ligand. The best performing allcopper DSC showed little change in performance over a period of 3 days (Table S2) indicating that the devices are stable.

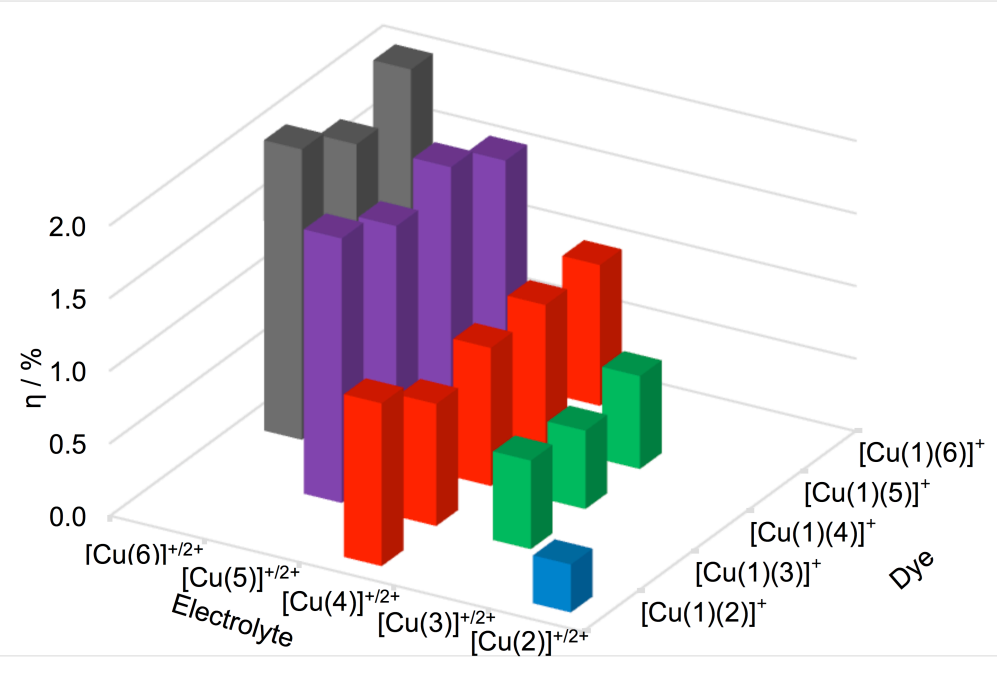

Fig. 4. Photoconversion efficiencies of the DSCs in Table 3 as a function of ancillary ligand and electrolyte. 


\subsection{Electrochemical impedance spectroscopy (EIS)}

Electrochemical impedance spectroscopy (EIS) is a valuable tool for the investigation of processes in DSCs, and has been applied to copper-based devices $[9,13,18,29]$. EIS measurements with DSCs containing $\mathbf{2}$ or $\mathbf{3}$ as ancillary ligand and in the electrolyte, and the best performing DSCs with electrolytes $\left[\mathrm{CuL}_{2}\right]^{+/ 2+}(\mathrm{L}=4-6)$ were performed 3 days after sealing the cells. EIS parameters are given in Table 4, and the Nyquist plots are shown in Fig. 5; the right-hand semicircle in each plot is associated with the diffusion resistance $\left(R_{d}\right)$. We focus on the effects of the electrolyte and its interaction with the dye/semiconductor interface. A known problem with $\mathrm{Cu}(\mathrm{I}) /(\mathrm{II})$ redox shuttles is the high $R_{d}[29]$. This was observed in all the DSCs (Table 4) where $R_{d}$ is between 115 and $1005 \Omega$. With a high $R_{d}$ value, the electron transport in the electrolyte is rather low and regeneration of the oxidized sensitizer is not optimal. This results in low $J_{\mathrm{Sc}}$ values (Table 3). Smaller $R_{d}$ values are associated with smaller molecular sizes of the redox couple. On the other hand, a high $R_{d}$ also results in a high recombination resistance $\left(R_{\text {rec }}\right)$ (Table 4$)$ between the semiconductor/dye/electrolyte interface because of low diffusion of reduced electrolyte species.

Table 4. EIS parameters of DSCs with the best-performing combination of dye and each electrolyte.

\begin{tabular}{|c|l|c|c|}
\hline Dye & Electrolyte & $R_{\text {rec }} / \Omega$ & $R_{d} / \Omega$ \\
\hline$[\mathrm{Cu}(\mathbf{1})(\mathbf{2})]^{+}$ & {$\left[\mathrm{Cu}(\mathbf{2})_{2}\right]^{+/ 2+}$} & 886 & 806 \\
\hline$[\mathrm{Cu}(\mathbf{1})(\mathbf{3})]^{+}$ & {$\left[\mathrm{Cu}(\mathbf{3})_{2}\right]^{+/ 2+}$} & 1195 & 1005 \\
\hline$[\mathrm{Cu}(\mathbf{1})(\mathbf{2})]^{+}$ & {$\left[\mathrm{Cu}(\mathbf{4})_{2}\right]^{+/ 2+}$} & 643 & 663 \\
\hline$[\mathrm{Cu}(\mathbf{1})(\mathbf{3})]^{+}$ & {$\left[\mathrm{Cu}(\mathbf{5})_{2}\right]^{+/ 2+}$} & 387 & 517 \\
\hline$[\mathrm{Cu}(\mathbf{1})(\mathbf{6})]^{+}$ & {$\left[\mathrm{Cu}(\mathbf{6})_{2}\right]^{+/ 2+}$} & 261 & 115 \\
\hline
\end{tabular}




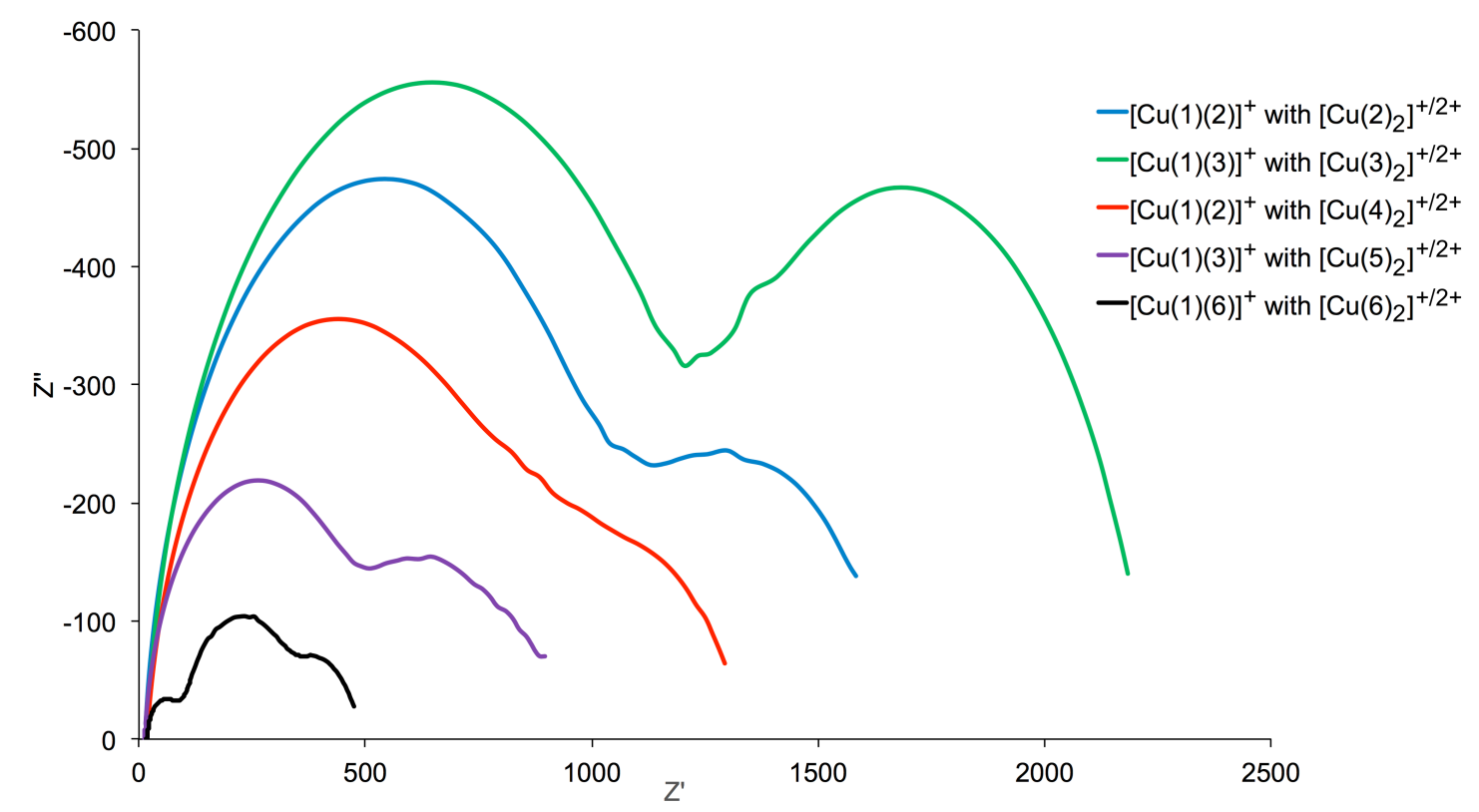

Fig. 5. Nyquist plots for DSCs containing the best-performing combination of dye and each electrolyte.

\section{Experimental}

\subsection{General}

${ }^{1} \mathrm{H}$ and ${ }^{13} \mathrm{C}$ NMR spectra were recorded on a Bruker Avance III-500 NMR spectrometer at $295 \mathrm{~K} ;{ }^{1} \mathrm{H}$ and ${ }^{13} \mathrm{C}$ chemical shifts were referenced to residual solvent peaks with respect to $\delta(\mathrm{TMS})=0 \mathrm{ppm}$. Spectra were assigned using COSY, NOESY, HMQC and HMBC methods. Solution absorption spectra were recorded on an Agilent 8453 spectrophotometer and solid state absorption spectra were recorded on a Cary 5000 spectrophotometer. Electrospray ionization (ESI) mass spectra were recorded on a Shimadzu LCMS-2020 instrument, and high resolution ESI mass spectra on a Bruker maXis 4G QTOF instrument.

Electrochemical measurements were made using a $\mathrm{CH}$ Instruments 900B potentiostat with glassy carbon, platinum wire and leakless $\mathrm{Ag}^{+} / \mathrm{AgCl}(\mathrm{eDAQ} \mathrm{ET069-}$ 1) as the working, counter, and reference electrodes, respectively. Compounds were dissolved in HPLC grade $\mathrm{CH}_{2} \mathrm{Cl}_{2}$ (ca. $10^{-5} \mathrm{~mol} \mathrm{dm}^{-3}$ ) containing $0.1 \mathrm{~mol} \mathrm{dm}^{-3}$ 
$\left[{ }^{\mathrm{n}} \mathrm{Bu}_{4} \mathrm{~N}\right]\left[\mathrm{PF}_{6}\right]$ as the supporting electrolyte; all solutions were degassed with argon. $\mathrm{Cp}_{2} \mathrm{Fe}$ was used as internal reference. The scan rate was $0.1 \mathrm{~V} \mathrm{~s}^{-1}$.

Compounds 1 [34], 2 [33] and 3 [40] were prepared as previously reported. Compounds $\mathbf{4}$ and $\mathbf{5}$ were purchased from Sigma-Aldrich and $\mathrm{TCl}$, respectively. Homoleptic copper $(\mathrm{I})$ complexes were made from $\left[\mathrm{Cu}\left(\mathrm{MeCN}_{4}\right]\left[\mathrm{PF}_{6}\right][41]\right.$ (see below); $\left[\mathrm{Cu}(2)_{2}\right]\left[\mathrm{PF}_{6}\right][34],\left[\mathrm{Cu}(4)_{2}\right]\left[\mathrm{PF}_{6}\right][35],\left[\mathrm{Cu}(5)_{2}\right]\left[\mathrm{PF}_{6}\right]$ [30] have previously been reported.

\section{$3.2\left[\mathrm{Cu}(3)_{2}\right]\left[\mathrm{PF}_{6}\right]$}

Compound $3(1.960 \mathrm{~g}, 6.04 \mathrm{mmol})$ and $\left[\mathrm{Cu}\left(\mathrm{MeCN}_{4}\right]\left[\mathrm{PF}_{6}\right](1.120 \mathrm{~g}, 3.01 \mathrm{mmol})\right.$ were dissolved in $\mathrm{CH}_{2} \mathrm{Cl}_{2}(25 \mathrm{~mL})$. The dark red solution was stirred overnight at room temperature and the solution was concentrated under vacuum. Diethyl ether was added to precipitate the product. The solid was filtered and dried to yield $\left[\mathrm{Cu}(3)_{2}\right]\left[\mathrm{PF}_{6}\right]$ as a dark red solid $(2.50 \mathrm{~g}, 2.92 \mathrm{mmol}, 97 \%) .{ }^{1} \mathrm{H}$ NMR $(500 \mathrm{MHz}$, $\left.\mathrm{CD}_{2} \mathrm{Cl}_{2}\right) \delta / \mathrm{ppm} 8.53\left(\mathrm{~m}, 1 \mathrm{H}, \mathrm{H}^{\mathrm{B} 6}\right), 8.45\left(\mathrm{~d}, J=8.2 \mathrm{~Hz}, 1 \mathrm{H}, \mathrm{H}^{\mathrm{B} 3}\right), 8.33\left(\mathrm{~s}, 1 \mathrm{H}, \mathrm{H}^{\mathrm{A} 3}\right)$, $8.12\left(\mathrm{~m}, 1 \mathrm{H}, \mathrm{H}^{\mathrm{B} 4}\right), 7.75-7.67$ (overlapping $\left.\mathrm{m}, 4 \mathrm{H}, \mathrm{H}^{\mathrm{C} 2+\mathrm{C} 3}\right), 7.65\left(\mathrm{~s}, 1 \mathrm{H}, \mathrm{H}^{\mathrm{A} 5}\right), 7.57(\mathrm{~m}$, $\left.1 \mathrm{H}, \mathrm{H}^{\mathrm{B} 5}\right), \quad 2.34\left(\mathrm{~s}, 3 \mathrm{H}, \mathrm{H}^{\mathrm{Me}}\right) \cdot{ }^{13} \mathrm{C}$ NMR $\left(126 \mathrm{MHz}, \mathrm{CD}_{2} \mathrm{Cl}_{2}\right) \delta / \mathrm{ppm} 158.4\left(\mathrm{C}^{\mathrm{A}}\right)$, $152.6\left(C^{A 2+B 2}\right), 149.8\left(C^{A 4}\right), 149.2\left(C^{B 6}\right), 138.6\left(C^{B 4}\right), 136.4\left(C^{C 1}\right), 133.2\left(C^{C 2 / C 3}\right)$, $129.3\left(C^{\mathrm{C} 2 / C 3}\right) 126.9\left(C^{B 5}\right), 124.8\left(C^{C 4}\right), 124.0\left(C^{A 5}\right), 122.7\left(C^{B 3}\right), 117.5\left(C^{A 3}\right), 25.5$ $\left(\mathrm{C}^{\mathrm{Me}}\right)$. ESI MS: $\mathrm{m} / \mathrm{z} 712.93\left[\mathrm{Cu}(3)_{2}\right]^{+}$(base peak, calc. 712.98 ). UV-VIS $\left(\mathrm{CH}_{2} \mathrm{Cl}_{2}, 5 \times\right.$ $\left.10^{-5} \mathrm{~mol} \mathrm{dm}^{-3}\right): \lambda / \mathrm{nm}\left(\varepsilon / \mathrm{dm}^{3} \mathrm{~mol}^{-1} \mathrm{~cm}^{-1}\right) 253 \mathrm{sh}$ (35600), 273 (47100), $304 \mathrm{sh}$ (27700), 347 sh (5100), 467 (7400).

\subsection{Compounds $6 \mathrm{a}$ and $6 \mathrm{~b}$}

Compounds $\mathbf{6 a}$ and $\mathbf{6 b}$ (see Scheme 2) were prepared according to the literature procedure [42]. 


\subsection{Compound 6c}

Compound 6c was prepared according to the literature procedure adapted to our substrate [43]. 6,6'-Dimethyl-4,4'-dinitro-2,2'-bipyridine (612 mg, $2.0 \mathrm{mmol}$ ) was suspended in $\mathrm{MeOH}$, then $\mathrm{K}_{2} \mathrm{CO}_{3}(691 \mathrm{mg}, 5 \mathrm{mmol})$ was added. The reaction mixture was refluxed overnight. The cooled to room temperature mixture was evaporated, then redissolved in $\mathrm{MeCN}$, filtrated and the filtrate was evaporated. Crude $6 \mathrm{c}$ was isolated as pale brown solid and was used without further purification (450 mg, 1.62 mmol, 81\%). ${ }^{1} \mathrm{H}$ NMR (500 MHz, DMSO-d 6 ) $\delta / p p m ~ 7.24\left(2 \mathrm{H}, \mathrm{H}^{\mathrm{A} 3}\right), 7.11\left(2 \mathrm{H}, \mathrm{H}^{\mathrm{A} 5}\right)$, $3.82\left(6 \mathrm{H}, \mathrm{H}^{\mathrm{OMe}}\right), 2.35\left(6 \mathrm{H}, \mathrm{H}^{\mathrm{Me}}\right) .{ }^{13} \mathrm{C}$ NMR (126 MHz, DMSO-d 6$) \delta / p p m 154.7\left(\mathrm{C}^{\mathrm{A} 4}\right)$, 148.6 $\left(\mathrm{C}^{\mathrm{A} 2 / \mathrm{A} 6}\right), 143.3\left(\mathrm{C}^{\mathrm{A} 2 / \mathrm{A} 6}\right), 112.5\left(\mathrm{C}^{\mathrm{A} 5}\right), 111.7\left(\mathrm{C}^{\mathrm{A} 3}\right), 56.2\left(\mathrm{C}^{\mathrm{OMe}}\right), 17.7\left(\mathrm{C}^{\mathrm{Me}}\right)$.

\subsection{Compound 6}

$\mathrm{PBr}_{3}$ (16.3 mmol, $1 \mathrm{M}$ solution in degassed $\mathrm{CH}_{2} \mathrm{Cl}_{2}$ ) was slowly added to a cooled (ice bath) suspension of $6 \mathrm{c}(450 \mathrm{mg}, 1.63 \mathrm{mmol})$ in $\mathrm{CH}_{2} \mathrm{Cl}_{2}(10 \mathrm{~mL})$. The reaction mixture was warmed to room temperature and then heated at reflux overnight, then cooled down to room temperature. The cooled solution was poured on ice, the $\mathrm{pH}$ adjusted to 10 with aqueous $1 \mathrm{M} \mathrm{NaOH}$ solution. The product was extracted with $\mathrm{CH}_{2} \mathrm{Cl}_{2}$. Compound 6 was isolated as a white solid (309 mg, $\left.1.26 \mathrm{mmol}, 77 \%\right)$. ${ }^{1} \mathrm{H}$ NMR (500 MHz, CDCl $\left.)_{3}\right) \delta / p p m ~ 7.76\left(d, J=1.1 \mathrm{~Hz}, 2 \mathrm{H}, \mathrm{H}^{\mathrm{A} 3}\right), 7.68(\mathrm{~d}, J=1.1 \mathrm{~Hz}$, $\left.2 \mathrm{H}, \mathrm{H}^{\mathrm{A} 5}\right), 3.92\left(\mathrm{~s}, 6 \mathrm{H}, \mathrm{H}^{\mathrm{OMe}}\right), 2.57\left(\mathrm{~s}, 6 \mathrm{H}, \mathrm{H}^{\mathrm{Me}}\right) .{ }^{13} \mathrm{C} \mathrm{NMR}\left(126 \mathrm{MHz}, \mathrm{CDCl}_{3}\right) \delta / \mathrm{ppm}$ $167.0\left(C^{A 4}\right), 159.3\left(C^{A 2 / A 6}\right), 157.7\left(C^{A 2 / A 6}\right), 109.8\left(C^{A 5}\right), 104.1\left(C^{A 3}\right), 55.3\left(C^{\mathrm{OMe}}\right), 24.8$ $\left(\mathrm{C}^{\mathrm{Me}}\right)$. ESI MS m/z: $245.10[6+\mathrm{H}]^{+}$(calc. 245.12).

\section{$3.6\left[\mathrm{Cu}(6)_{2}\right]\left[\mathrm{PF}_{6}\right]$}


A solution of $\left[\mathrm{Cu}(\mathrm{MeCN})_{4}\right]\left[\mathrm{PF}_{6}\right](234 \mathrm{mg}, 0.62 \mathrm{mmol})$ in $\mathrm{CH}_{2} \mathrm{Cl}_{2}(4 \mathrm{~mL})$ was added dropwise to a solution of 6 (309 $\mathrm{mg}, 1.26 \mathrm{mmol})$ in $\mathrm{CH}_{2} \mathrm{Cl}_{2}(6 \mathrm{~mL})$. The red solution was stirred for 30 min and then $\mathrm{Et}_{2} \mathrm{O}(15 \mathrm{~mL})$ was added, the mixture was filtered. The solid was collected, washed with $\mathrm{EtOH}$ and $\mathrm{Et}_{2} \mathrm{O}$, then dried. $\left[\mathrm{Cu}(6)_{2}\right]\left[\mathrm{PF}_{6}\right]$ was obtained as a dark orange solid (365 mg, $0.53 \mathrm{mmol}, 83 \%) .{ }^{1} \mathrm{H}$ NMR $(500 \mathrm{MHz}$, DMSO-d $\left.\mathrm{d}_{6}\right) \delta / \mathrm{ppm} 8.08\left(4 \mathrm{H}^{\mathrm{A3}}\right), 7.19\left(4 \mathrm{H}^{\mathrm{A} 5}\right), 3.99\left(12 \mathrm{H}^{\mathrm{OMe}}\right), 2.14\left(12 \mathrm{H}^{\mathrm{Me}}\right) \cdot{ }^{13} \mathrm{C} \mathrm{NMR}$ $\left(126 \mathrm{MHz}, \mathrm{DMSO}-\mathrm{d}_{6}\right) \delta / \mathrm{ppm} 166.9\left(\mathrm{C}^{\mathrm{A} 2}\right), 158.0\left(\mathrm{C}^{\mathrm{A} 4}\right), 152.9\left(\mathrm{C}^{\mathrm{A} 6}\right), 110.9\left(\mathrm{C}^{\mathrm{A} 5}\right)$, $106.7\left(\mathrm{C}^{\mathrm{A} 3}\right), 56.1\left(\mathrm{C}^{\mathrm{OMe}}\right), 24.5\left(\mathrm{C}^{\mathrm{Me}}\right)$. ESI MS: m/z $551.16\left[\mathrm{Cu}(6)_{2}\right]^{+}$(calc. 551.17). High resolution ESI MS: m/z $551.1720\left[\mathrm{Cu}(6)_{2}\right]^{+}$(calc. 551.1714), $245.1285[6+\mathrm{H}]^{+}$ (calc. 245.1285). UV-VIS $\left.\mathrm{CH}_{2} \mathrm{Cl}_{2}, 5 \times 10^{-5} \mathrm{~mol} \mathrm{dm}^{-3}\right): \lambda / \mathrm{nm}\left(\varepsilon / \mathrm{dm}^{3} \mathrm{~mol}^{-1} \mathrm{~cm}^{-}\right) 269$ (43700), 290 (24900), 335 (5800), 444 (5500).

\subsection{Solar cell fabrication}

Each working electrode was made from an FTO glass plate (Solaronix TCO22-7, 2.2 $\mathrm{mm}$ thickness, sheet resistance $\approx 7 \Omega$ square $^{-1}$ ) which was cleaned by sonicating in a $2 \%$ surfactant solution in milliQ water (Sonoswiss cleaner, SW-C L2), and rinsed with milliQ water and EtOH. After surface activation in a UV-O ${ }_{3}$ system (Model 256-220, Jelight Company Inc) for $18 \mathrm{~min}$, the FTO plates were immersed in aqueous $\mathrm{TiCl}_{4}$ (40 $\mathrm{mmol} \mathrm{dm}^{-3}$ ) at $70{ }^{\circ} \mathrm{C}$ for $30 \mathrm{~min}$, and then washed with milliQ water and $\mathrm{EtOH}$. The electrodes were dried in $\mathrm{N}_{2}$ and a layer of $\mathrm{TiO}_{2}$ paste (Dyenamo, DN-GPS-18TS) was screen printed (90T, Serilith AG, Switzerland). The printed plates were kept in an EtOH chamber for 3 min for all printing cycles, to reduce surface irregularities of the printed layer and dried for $6 \mathrm{~min}$ at $125^{\circ} \mathrm{C}$ on a heating plate. The screen printing process was repeated 4 times, and then a final scattering layer was printed on top (Dyenamo, DN-GPS-220S). The electrodes were gradually heated at $75{ }^{\circ} \mathrm{C}$ for 30 min, at $135{ }^{\circ} \mathrm{C}$ for $15 \mathrm{~min}$, at $325^{\circ} \mathrm{C}$ for $5 \mathrm{~min}$, at $375^{\circ} \mathrm{C}$ for $5 \mathrm{~min}$, at $450{ }^{\circ} \mathrm{C}$ for 15 
min and at $500{ }^{\circ} \mathrm{C}$ for $15 \mathrm{~min}$. The annealed $\mathrm{TiO}_{2}$ film was post-treated with $40 \mathrm{mmol}$ $\mathrm{dm}^{-3}$ aqueous $\mathrm{TiCl}_{4}$ solution, rinsed with milliQ water and $\mathrm{EtOH}$ and sintered at 500 ${ }^{\circ} \mathrm{C}$ for $30 \mathrm{~min}$. The electrodes were cooled to ca. $80^{\circ} \mathrm{C}$ and immersed in a $1 \mathrm{mM}$ DMSO solution of the anchoring ligand for ca. $20 \mathrm{~h}$. The colourless electrodes were removed from the solution, washed with DMSO and $\mathrm{EtOH}$ and dried in a stream of $\mathrm{N}_{2}$. The electrodes with adsorbed anchoring ligand were immersed in a $0.1 \mathrm{mM}$ $\mathrm{CH}_{2} \mathrm{Cl}_{2}$ solution of $\left[\mathrm{CuL}_{2}\right]\left[\mathrm{PF} F_{6}\right](\mathrm{L}=2-6)$ for $72 \mathrm{~h}$ to give red-orange coloured electrodes. The electrodes were removed from the solution and were washed with $\mathrm{CH}_{2} \mathrm{Cl}_{2}$ and dried under a stream of $\mathrm{N}_{2}$. The reference electrode was made by dipping a commercial electrode in a $0.3 \mathrm{mM}$ EtOH solution of dye N719 (Solaronix) for 3 days. After soaking in the dye-baths, the electrodes were removed, washed with the same solvent as used in the dye-bath and dried with a heat gun.

Each counter electrode was commercially available from Solaronix (Test Cell Platinum Electrodes Drilled). The electrodes were rinsed with $\mathrm{EtOH}$ and dried on a heating plate at $500{ }^{\circ} \mathrm{C}$ for $30 \mathrm{~min}$. The $\mathrm{TiO}_{2}$ electrodes and Pt counter-electrodes were assembled using thermoplast hot-melt sealing foil (Solaronix, Test Cell Gaskets, made from Meltonix 1170-60 sealing film, 60 microns thick) by heating while pressing them together. The electrolytes (see below) were introduced into the cell by vacuum backfilling. The hole on the counter electrode was finally sealed using hotmelt sealing foil and a cover glass.

The solar cell measurements used fully masked cells using black coloured copper sheet with a single aperture placed over the screen printed dye-sensitized $\mathrm{TiO}_{2}$ circle. The area of the aperture in the mask was smaller than the active area of the dye-sensitized $\mathrm{TiO}_{2}\left(0.237 \mathrm{~cm}^{2}\right)$. For complete masking, tape was also applied over the edges and rear of the cell. Current density-voltage $(J-V)$ measurements were made by irradiating from behind with a LOT Quantum Design LS0811 
instrument $\left(100 \mathrm{~mW} \mathrm{~cm}{ }^{-2}=1\right.$ sun at $A M$ 1.5) and the simulated light power was calibrated with a silicon reference cell. The reference dye was N719 (Solaronix).

The external quantum efficiency (EQE) measurements were performed on a Spe-Quest quantum efficiency setup from Rera Systems (Netherlands) equipped with a $100 \mathrm{~W}$ halogen lamp (QTH) and a lambda 300 grating monochromator from Lot Oriel. The monochromatic light was modulated to $1 \mathrm{~Hz}$ using a chopper wheel from ThorLabs. The cell response was amplified with a large dynamic range IV converter from CVI Melles Griot and then measured with a SR830 DSP Lock-In amplifier from Stanford Research.

Electrochemical impedance spectroscopy (EIS) measurements were carried out on a ModuLab® XM PhotoEchem photoelectrochemical measurement system from Solartron Analytical or a VoltaLab PGZ 402 potentiostat from Radiometer Analytical. The impedance was measured in galvanostatic mode at open-circuit potential of the cell at different light intensities $(590 \mathrm{~nm})$ in the frequency range 0.05 $\mathrm{Hz}$ to $400 \mathrm{kHz}$ (ModuLab® XM) or $100 \mathrm{kHz}$ (VoltaLab PGZ ) using an amplitude of $10 \mathrm{mV}$. The impedance data were analysed using ZView® software (Scribner Associates Inc.).

\subsection{Electrolyte preparation}

The copper(II) complexes were prepared as follows. $0.20 \mathrm{mmol}$ copper(I) complex $\left(\left[\mathrm{Cu}(2)_{2}\right]\left[\mathrm{PF}_{6}\right], \quad\left[\mathrm{Cu}(3)_{2}\right]\left[\mathrm{PF}_{6}\right], \quad\left[\mathrm{Cu}(\mathbf{4})_{2}\right]\left[\mathrm{PF}_{6}\right], \quad\left[\mathrm{Cu}(\mathbf{5})_{2}\right]\left[\mathrm{PF}_{6}\right]\right.$ or $\left.\quad\left[\mathrm{Cu}(\mathbf{6})_{2}\right]\left[\mathrm{PF}_{6}\right]\right)$ was dissolved in a minimum volume of dry acetonitrile and $0.24 \mathrm{mmol}(1.2$ eq.) of [NO][BF $\left.{ }_{4}\right]$ was added. Over a period of $1 \mathrm{~h}$ stirring, the solutions turned green. Then $1.00 \mathrm{mmol}$ (5 eq.) of $\mathrm{NH}_{4} \mathrm{PF}_{6}$ dissolved in $\mathrm{MeOH}$ was added and the solutions were stirred for another $1 \mathrm{~h}$. $\mathrm{Et}_{2} \mathrm{O}$ was then added to the solutions to precipitate the copper(II) complexes, which were collected by filtration and washed with water and 
$\mathrm{Et}_{2} \mathrm{O}$. ESI-MS (MeOH with $\mathrm{CH}_{2} \mathrm{Cl}_{2}$ solutions): $\left[\mathrm{Cu}(2)_{2}\right]\left[\mathrm{PF}_{6}\right]_{2}: \mathrm{m} / \mathrm{z} 1050.80\left[\mathrm{Cu}(2)_{2}\right]^{+}$ (calc. 1050.90), $494.94[2+\mathrm{H}]^{+}$(calc. 494.99). $\left[\mathrm{Cu}(3)_{2}\right]\left[\mathrm{PF}_{6}\right]_{2}: \mathrm{m} / \mathrm{z} 712.93\left[\mathrm{Cu}(3)_{2}\right]^{+}$ (calc. 712.98), $356.43\left[\mathrm{Cu}(3)_{2}\right]^{2+}$ (calc. 356.49). [Cu(4) $\left.)_{2}\right]\left[\mathrm{PF}_{6}\right]_{2}: \mathrm{m} / \mathrm{z} 431.11\left[\mathrm{Cu}(4)_{2}\right]^{+}$ (calc. 431.13). $\left[\mathrm{Cu}(5)_{2}\right]\left[\mathrm{PF}_{6}\right]_{2}: \mathrm{m} / \mathrm{z} 498.10\left[\mathrm{Cu}(\mathbf{5})_{2}+\mathrm{F}\right]^{+}$(calc. 498.13), $479.07\left[\mathrm{Cu}(5)_{2}\right]^{+}$ (calc. 479.13), $239.69\left[\mathrm{Cu}(5)_{2}\right]^{2+}$ (calc. 239.57). $\left[\mathrm{Cu}(\mathbf{6})_{2}\right]\left[\mathrm{PF}_{6}\right]_{2}: \mathrm{m} / \mathrm{z} 551.13\left[\mathrm{Cu}(6)_{2}\right]^{+}$ (calc. 551.17). For singly or doubly charged ions, the peak separations in each peak envelope were in accord with the corresponding charge.

\section{Conclusions}

With a target of developing DSCs containing Earth-sustainable components, we have investigated the performances of DSCs featuring structurally simple heteroleptic bis(diimine)copper(I) sensitizers coupled with homoleptic bis(diimine)copper(I)/(II) redox shuttles. Photoconversion efficiencies are strongly influenced by the electrolyte, with values of $J_{S C}$ increasing in the order $\left[\mathrm{Cu}(\mathbf{6})_{2}\right]^{+/ 2+}>\left[\mathrm{Cu}(\mathbf{5})_{2}\right]^{+/ 2+}>$ $\left[\mathrm{Cu}(4)_{2}\right]^{+/ 2+}>\left[\mathrm{Cu}(3)_{2}\right]^{+/ 2+}>\left[\mathrm{Cu}(2)_{2}\right]^{+/ 2+}$. For electrolytes $\left[\mathrm{Cu}(\mathbf{6})_{2}\right]^{+/ 2+},\left[\mathrm{Cu}(\mathbf{5})_{2}\right]^{+/ 2+}$, $\left[\mathrm{Cu}(4)_{2}\right]^{+/ 2+}$ and $\left[\mathrm{Cu}(3)_{2}\right]^{+/ 2+}$, values of $V_{\mathrm{OC}}$ exceed that of a DSC with N719 with an $\mathrm{I}^{-}$ $/ I_{3}{ }^{-}$electrolyte. The best performing combination was $[\mathrm{Cu}(1)(6)]^{+}$as dye and $\left[\mathrm{Cu}(6)_{2}\right]^{+/ 2+}$ as redox couple, where a photoconversion efficiency of $2.06 \%(38.1 \%$ relative to N719) was achieved. Even without structural optimization, this study confirms the viability of all copper-based DSCs, opening the way to DSCs with Earth abundant components.

Note added in revision: After submission of this manuscript, we bacame aware of a near-simultaneous publication describing similar all-coppper DSCs [44]. We are pleased that this work supports the findings that we report in our paper. 


\section{Appendix A. Supplementary data}

Supplementary data related to this article can be found at http:// dx.doi.org..........

\section{Acknowledgements}

We thank the Swiss National Science Foundation (Grant number 200020_162631),

Swiss Nanoscience Institute (funding of the EIS instrument) and the University of Basel for support. We thank Fabian Brunner and Jens Top for assistance with measurements.

\section{References}

[1] World Meteorological Organization, WMO Greenhouse Gas Bulletin, 2017, No. 13.

[2] Knutti R, Rugenstein M A A, Hegerl G C. Beyond equilibrium climate sensitivity. Nature Geoscience 2017; 10; 727-736.

[3] O'Regan B, Grätzel M. A low-cost, high-efficiency solar cell based on dyesensitized colloidal TiO2 films. Nature 1991; 353; 737-740.

[4] Hagfeldt A, Boschloo G, Sun L, Kloo L, Pettersson H. Dye sensitized solar cells. Chem Rev 2010; 110; 6595-6663.

[5] See for example: Yella A, Lee H.-W, Tsao H N, Yi C, Chandiran A K, Nazeeruddin M K, Diau E W-G, Yeh C-Y, Zakeeruddin S M, Grätzel M. Porphyrin-sensitized solar cells with cobalt (II/III)-based redox electrolyte exceed 12 percent efficiency. Science 2011; 334; 629-634; Higashino T, Imahori H. Porphyrins as excellent dyes for dye-sensitized solar cells: recent developments and insights. Dalton Trans 2015; 44; 448-463; Xie Y, Tang Y, Wu W, Wang Y, Liu J, Li X, Tian H, Zhu W-H. Porphyrin Cosensitization for a Photovoltaic Efficiency of 11.5\%: A Record for NonRuthenium Solar Cells Based on lodine Electrolyte. J Am Chem Soc 2015; 137; 14055-14058; Mathew S, Yella A, Gao P, Humphry-Baker R, Curchod 
B F E, Ashari-Astani N, Tavernelli I, Rothlisberger U, Nazeeruddin Md K, Grätzel M. Dye-sensitized solar cells with $13 \%$ efficiency achieved through the molecular engineering of porphyrin sensitizers. Nature Chem 2014; 6; 242-247; Kakiage K, Aoyama Y, Yano T, Oya K, Fujisawa J-i, Hanaya M. Highly-efficient dye-sensitized solar cells with collaborative sensitization by silyl-anchor and carboxy-anchor dyes. Chem Commun 2015; 51; $15894-$ 15897; Kakiage K, Aoyama Y, Yano T, Oya K, Kyomen T, Hanaya M. Fabrication of a high-performance dye-sensitized solar cell with $12.8 \%$ conversion efficiency using organic silyl-anchor dyes. Chem Commun 2015; 51; 6315-6317; Yao Z, Zhang M, Wu H, Yang L, Li R, Wang P. Donor/Acceptor Indenoperylene Dye for Highly Efficient Organic DyeSensitized Solar Cells. J Am Chem Soc 2015; 137; 3799-3802; Gong J, Sumathy K, Qiao Q, Zhou Z. Review on dye-sensitized solar cells (DSSCs): Advanced techniques and research trends. Renew. Sust. Energ. Rev. 2017; 68; 234-246.

[6] Emsley J The Elements, 3rd Ed. 1998, Clarendon Press, Oxford.

[7] Housecroft C E, Constable E C. The Emergence of copper(I)-based dye sensitized solar cells. Chem Soc Rev 2015; 44; 8386-8398.

[8] Magni M, Biagini P, Colombo A, Dragonetti C, Roberto D, Valore A. Versatile copper complexes as a convenient springboard for both dyes and redox mediators in dye sensitized solar cells. Coord Chem Rev 2016; 322; 69-93.

[9] Malzner F J, Prescimone A, Constable E C, Housecroft C E, Willgert M. Exploring simple ancillary ligands in copper-based dye-sensitized solar cells: effects of a heteroatom switch and of co-sensitization. J Mater Chem A 2017; 5; 4671-4685.

[10] Brauchli S Y, Malzner F J , Constable E C, Housecroft C E. Copper(I)-based dye-sensitized solar cells with sterically demanding anchoring ligands: bigger is not always better. RSC Adv 2015; 5; 48516-48525.

[11] Malzner F J, Brauchli S Y, Constable E C, Housecroft C E, Neuburger M. Halos show the path to perfection: peripheral iodo-substituents improve the efficiencies of bis(diimine)copper(I) dyes in dye-sensitized solar cells. RSC Adv 2014; 4; 48712-48723. 
[12] Büttner A, Brauchli S Y, Vogt R, Constable E C, Housecroft C E. Combining phosphonic acid-functionalized anchoring ligands with asymmetric ancillary ligands in bis(diimine)copper(I) dyes for dye-sensitized solar cells. RSC Adv 2016; 6; 5205-5213.

[13] Baumgartner Y, Klein Y M, Constable E C, Housecroft C E, Willgert M. Cyanoacrylic- and (1-cyanovinyl)phosphonic acid anchoring ligands for application in copper-based dye-sensitized solar cells. RSC Adv 2016; 6; 86220-86231.

[14] Brunner F, Klein Y M, Keller S, Morris C D, Prescimone A, Constable E C, Housecroft C E. The beneficial effects of trifluoromethyl-substituents on the photoconversion efficiency of copper(I) dyes in dye-sensitized solar cells. RSC Adv. 2015; 5; 58694-58703.

[15] Fürer S O, Luu L Y N, Bozic-Weber B, Constable E C, Housecroft C E. Improving performance of copper(I)-based dye sensitized solar cells through $\mathrm{I}_{3}{ }^{-} \mathrm{II}^{-}$electrolyte manipulation. Dyes Pigm 2016; 132; 72-78.

[16] Sandroni M, Favereau L, Planchat A, Akdas-Kilig H, Szuwarski N, Pellegrin Y, Blart E, Le Bozec H, Boujtita M, Odobel F. Heteroleptic copper(I)polypyridine complexes as efficient sensitizers for dye sensitized solar cells. J Mater Chem A 2014; 2; 9944-9947.

[17] Malzner F J, Willgert M, Constable E C, Housecroft C E. The way to panchromatic copper(I)-based dye-sensitized solar cells: co-sensitization with the organic dye SQ2. J Mater Chem A 2017; 5; 13717-13729.

[18] Fürer S O, Bozic-Weber B, Schefer T, Wobill C, Constable E C, Housecroft $\mathrm{C} \mathrm{E}$, Willgert $\mathrm{M}$. Understanding why replacing $\mathrm{I}_{3}{ }^{-} / \mathrm{I}^{-}$by cobalt(II)/(III) electrolytes in bis(diimine)copper(I)-based dye-sensitized solar cells improves performance. J Mater Chem A 2016; 4; 12995-13004.

[19] Wang M, Grätzel C, Zakeeruddin S M, Grätzel M. Recent developments in redox electrolytes for dye-sensitized solar cells. Energy Environ Sci 2012; 5; 9394-9405.

[20] Wu J, Lan Z, Lin J, Huang M, Huang Y, Fan L, Luo G. Electrolytes in DyeSensitized Solar Cells. Chem Rev 2015; 115; 2136-2173.

[21] Hattori S, Wada Y, Yanagida S, Fukuzumi S. Blue Copper Model Complexes with Distorted Tetragonal Geometry Acting as Effective Electron-Transfer 
Mediators in Dye-Sensitized Solar Cells. J Am Chem Soc 2005; 127; 96489654.

[22] Brugnati M, Caramori S, Cazzanti S, Marchini L, Argazzi R, Bignozzi C A. Electron Transfer Mediators for Photoelectrochemical Cells Based on $\mathrm{Cu}(\mathrm{I})$ Metal Complexes. Int J Photoenergy 2007; article 80756.

[23] Bai Y, Yu Q, Cai N, Wang Y, Zhanga M, Wang P. High-efficiency organic dye-sensitized mesoscopic solar cells with a copper redox shuttle. Chem Commun 2011; 47; 4376-4378.

[24] Freitag M, Giordano F, Yang W, Pazoki M, Hao Y, Zietz B, Grätzel M, Hagfeldt A, Boschloo G. Copper Phenanthroline as a Fast and HighPerformance Redox Mediator for Dye-Sensitized Solar Cells. J Phys Chem C 2016; 120; 9595-9603.

[25] Kavan L, Saygili Y, Freitag M, Zakeeruddin S M, Hagfeldt A, Grätzel M. Electrochemical Properties of $\mathrm{Cu}(\mathrm{II} / \mathrm{l})$-Based Redox Mediators for DyeSensitized Solar Cells. Electrochim Acta 2017; 227; 194-202.

[26] Saygili Y, Söderberg M, Pellet N, Giordano F, Cao Y, Belen Muñoz-García A, Zakeeruddin S M, Vlachopoulos N, Pavone M, Boschloo G, Kavan L, Moser J.-E, Grätzel M, Hagfeldt A, Freitag M. Copper Bipyridyl Redox Mediators for Dye-Sensitized Solar Cells with High Photovoltage. J Am Chem Soc 2016; 138; 15087-15096.

[27] Colombo A, Di Carlo G, Dragonetti C, Magni M, Orbelli Biroli A, Pizzotti M, Roberto D, Tessore F, Benazzi E, Bignozzi C A, Casarin L, Caramori S. Coupling of Zinc Porphyrin Dyes and Copper Electrolytes: A Springboard for Novel Sustainable Dye-Sensitized Solar Cells. Inorg Chem 2017; 56; 14189-14197.

[28] Freitag M, Teuscher J, Saygili Y, Zhang X, Giordano F, Liska P, Hua J, Zakeeruddin S M, Moser J-E, Grätzel M, Hagfeldt A. Dye-sensitized solar cells for efficient power generation under ambient lighting. Nature Photonics 2017; 11; 372-378.

[29] Cong J, Kinschel D, Daniel Q, Safdari M, Gabrielsson E, Chen H, Svensson $\mathrm{PH}$, Sunce L, Kloo L. Bis(1,1-bis(2-pyridyl)ethane)copper(I/II) as an efficient redox couple for liquid dye-sensitized solar cells. J Mater Chem A 2016; 4; 14550-14554.

[30] Magni M, Giannuzzi R, Colombo A, Cipolla M P, Dragonetti C, Caramori S, 
Carli S, Grisorio R, Suranna G P, Bignozzi C A, Roberto D, Manca M.

Tetracoordinated Bis-phenanthroline Copper-Complex Couple as Efficient Redox Mediators for Dye Solar Cells. Inorg Chem 2016; 55; 5245-5253.

[31] Martin C J, Bozic-Weber B, Constable E C, Glatzel T, Housecroft C E, Wright I A. Using scanning electrochemical microscopy as a tool to examine copper(I) sensitizers for dye sensitized solar cells. J Phys Chem C; 2014; 118; 16912-16918.

[32] Bozic-Weber B, Constable E C, Housecroft C E, Kopecky P, Neuburger M, Zampese J A. The intramolecular aryl embrace: from light emission to light absorption. Dalton Trans 2011; 40; 12584-12594.

[33] Bozic-Weber B, Brauchli S Y, Constable E C, Fürer S O, Housecroft C E, Wright I A. Hole-transport functionalized copper(I) dye sensitized solar cells. Phys Chem Chem Phys 2013; 15; 4500-4504.

[34] Bozic-Weber B, Brauchli S Y, Constable E C, Fürer S O, Housecroft, C E, Malzner F J, Wright I A, Zampese J A. Improving the photoresponse of copper $(\mathrm{I})$ dyes in dye-sensitized solar cells by tuning ancillary and anchoring ligand modules. Dalton Trans 2013; 42; 12293-12308.

[35] Bozic-Weber B, Chaurin V, Constable E C, Housecroft C E, Meuwly M, Neuburger M, Rudd J A, Schönhofer E, Siegfried L. Exploring copper(I)based dye-sensitized solar cells: a complementary experimental and TDDFT investigation. Dalton Trans 2012; 41; 14157-14169.

[36] Eggleston M K, McMillin D R, Koenig K S, Pallenberg A J. Steric Effects in the Ground and Excited States of $\mathrm{Cu}(\mathrm{NN})_{2}{ }^{+}$Systems. Inorg Chem 1997; 36; 172-176.

[37] Pavlishchuk V V, Addison A W. Conversion constants for redox potentials measured versus different reference electrodes in acetonitrile solutions at $25^{\circ} \mathrm{C}$. Inorg Chim Acta 2000; 298; 97-102.

[38] Ishizuka T, Tobita K, Yano Y, Shiota Y, Yoshizawa K, Fukuzumi S, Kojima T. Proton-coupled electron shuttling in a covalently linked ruthenium-copper heterodinuclear complex. J Am Chem Soc 2011; 133; 18570-18573.

[39] Ferdowski P, Saygili Y, Zakeeruddin S M, Mokhtari J, Grätzel M, Hagfeldt A, Kavan L. Alternative bases to 4-tert-butylpyridine for dye-sensitized solar cells employing copper redox mediator. Electrochim Acta 2018; 265; $194-$ 201. 
[40] Schönhofer E, Bozic-Weber B, Martin C J, Constable E C, Housecroft C E, Zampese J A. 'Surfaces-as-ligands, surfaces-as-complexes' strategies for copper(I) dye-sensitized solar cells. Dyes Pigm 2015; 115; 154-165.

[41] Kubas G J. Tetrakis(acetonitrile)copper(1+) hexafluorophosphate(1-). Inorg Synth 1990; 28; 68-70.

[42] Kirsanov D O, Borisova N E, Reshetova M D, Ivanov A V, Korotkov L A, Eliseev I I, Alyapyshev M Yu, Spiridonov I G, Legin A V, Vlasov Yu G, Babain V A. Novel diamides of 2,2'-dipyridyl-6,6'-dicarboxylic acid: synthesis, coordination properties, and possibilities of use in electrochemical sensors and liquid extraction. Russian Chem Bull 2012; 61; 881-890.

[43] Kühler T C, Fryklund J, Bergman N, Weilitz J, Lee A, Larsson H. StructureActivity Relationship of Omeprazole and Analogs as Helicobacter pylori Urease Inhibitors. J Med Chem 1995; 38; 4906-4916.

[44] Dragonetti C, Magni M, Colombo A, Melchiorre F, Biagini P, Roberto D. Coupling of a Copper Dye with a Copper Electrolyte: A Fascinating Springboard for Sustainable Dye-Sensitized Solar Cells. ACS Appl. Energy Mater. 2018; 1; 751-756. 